\title{
THREE-SECTOR PARTNERSHIP DALAM PEMBANGUNAN EKONOMI
}

\author{
Fitrotun Niswah \\ Eva Hany Fanida
}

\begin{abstract}
Dosen Program Studi Ilmu Administrasi Negara Universitas Negeri Surabaya vita.unesa@yahoo.com; efanida@yahoo.com
\end{abstract}

\begin{abstract}
Abstrak
Pembangunan ekonomi akan mendorong peningkatan kesejahteraan masyarakat, untuk itu maka upaya penataan sistem perekonomian yang dicanangkan melalui Program Stabilisasi dan Rehabilitasi Ekonomi Menjadi keharusan. Pertumbuhan ekonomi yang pesat mendorong penyediaan berbagai sarana dan prasarana perekonomian penting yang dibutuhkan untuk mempercepat pembangunan ekonomi. Namun, upaya tersebut hanya mungkin berhasil secara berkelanjutan jika tercipta partisipasi aktif dan usaha sungguh-sungguh dari tiga unsur, yaitu pemerintah, sektor swasta dan masyarakat.Dalam rangka terciptanya pembangunan yang berkelanjutan maka program CSR harus dilakukan seluruh perusahaan di dunia.

Intinya terfokus pada pembangunan ekonomi yang lebih baik dibutuhkan three-sector partnership yakni kemitraan antara pemerintah, sektor swasta (perusahaan) dan masyarakat atau Lembaga Swadaya Masyarakat (LSM). Melalui CSR, perusahaan tidak lagi hanya berpijak pada single bottom line, yakni hanya konsen pada kondisi keuangan saja, akan tetapi juga harus mengembangkan triple bottom line. Perusahaan juga harus berpikir dan bertindak guna tingkatkan kesejahteraan masyarakat di sekitar industrinya. Para pelaku dan pemerhati CSR harus meyakini bahwa proses pembangunan berkelanjutan secara utuh dimulai dengan adanya koordinasi yang baik antara pemerintah, swasta, dan masyarakat secara keseluruhan .
\end{abstract}

Kata Kunci : Three-Sector Partnership, Pembangunan ekonomi

\section{PENDAHULUAN}

Pembangunan ekonomi bukan sebuah upaya yang sekali jadi, namun diperlukan serangkaian tahapan yang sistematis, terukur dan berkesinambungan dengan dukungan dari seluruh komponen baik dari pemerintah, sektor swasta dan seluruh lapisan masyarakat. Pembangunan ekonomi diarahkan pada kegiatan yang ramah lingkungan sehingga pencemaran dan penurunan kualitas lingkungan dapat dikendalikan, serta diarahkan pula pada pengembangan ekonomi yang lebih memanfaatkan jasa lingkungan. Pemulihan dan rehabilitasi kondisi lingkungan hidup diprioritaskan pada upaya untuk meningkatkan daya dukung lingkungan dalam menunjang pembangunan berkelanjutan. Program Kemitraan Pembangunan Berkelanjutan hakekatnya adalah menyatukan para pemangku kepentingan untuk mengidentifikasi, mengembangkan dan menguji solusi baru. Sebagai langkah awal, hal ini dilakukan melalui pengembangan strategi berwawasan lingkungan Kemitraan publik-swasta yang inovatif ini adalah kolaborasi baru antara Lembaga Swadaya Masyarakat (LSM), sektor swasta dan pemerintah untuk menciptakan konsep Three-Sector Partnership dalam Pembangunan Ekonomi. Hal ini untuk 
membuktikan bahwa pertumbuhan ekonomi, kesejahteraan masyarakat melalui konsep Three-Sector Partnership dalam Pembangunan Ekonomi dapat berjalan bersama dengan harmonis.

Keragaman investasi dan pendekatan inovatif konsep Three-Sector Partnership dalam Pembangunan Ekonomi sangat diperlukan agar secara efektif bersama sama menyediakan peluang ekonomi, penghidupan serta peningkatan pendapatan bagi masyarakat. Senada dengan asumsi tersebut, kemitraan dalam pembangunan seharusnya akan makin meningkat sejalan dengan meningkatnya kemampuan masyarakat dan dunia usaha untuk berpartisipasi dalam pembangunan.

Agar terwujud kemitraan yang saling mendukung, maka perlu diciptakan iklim yang menggairahkan dengan perangkat dan pranata yang memadai. Kemitraan pada hakikatnya merupakan wujud yang ideal dalam peranserta masyarakat dalam pembangunan. Kemitraan didasari atas hubungan antarpelaku yang bertumpu pada ikatan usaha yang saling menunjang dan saling menguntungkan, serta saling menghidupi berdasarkan asas kesetaraan dan kebersamaan. Setiap pelaku usaha memiliki potensi, kemampuan dan keistimewaan sendiri, walaupun berbeda ukuran, jenis, sifat, dan tempat usahanya. Setiap pelaku usaha juga memiliki kelebihan dan kekurangannya. Dengan kelebihan dan kekurangan itu timbul kebutuhan kerjasama dan kemitraan. Dengan demikian, kelebihan-kelebihan akan dilipatgandakan dengan memaksimalkan manfaat yang mungkin diperoleh. Sedangkan kekurangan-kekurangan dapat diusahakan untuk dikurangi, atau bahkan dihilangkan sama sekali, dengan kerjasama yang saling menutupinya. Kemitraan dalam pembangunan pada dasarnya mengandung hakekat keadilan dalam perolehan keuntungan dan manfaat, pembebanan biaya dan penanggungan resiko yang timbul dalam kegiatan usaha tersebut. Dengan demikian, kemitraan yang dikembangkan adalah kemitraan yang setara antara para pelaku sesuai dengan kemampuan kontribusinya.Kemitraan yang setara memerlukan pula pemahaman yang kuat terhadap hak dan tanggung jawab serta peranan dari masing-masing pelaku.

\section{PEMBAHASAN}

Indonesia yang Maju dan Mandiri menuntut kemampuan ekonomi untuk tumbuh , berkelanjutan, mampu meningkatkan pemerataan dan kesejahteraan masyarakat secara luas, serta berdaya saing tinggi didukung oleh penguasaan dan penerapan ilmu pengetahuan dan teknologi di dalam mengembangkan sumber-sumber daya pembangunan. Peranan pemerintah yang efektif dan optimal diwujudkan sebagai fasilitator, regulator, sekaligus sebagai katalisator pembangunan di berbagai tingkat guna efisiensi dan efektivitas pelayanan publik, terciptanya lingkungan usaha yang kondusif dan berdaya saing, dan terjaganya keberlangsungan mekanisme pasar. Kelembagaan ekonomi dikembangkan sesuai dinamika kemajuan ekonomi dengan menerapkan prinsip-prinsip kepemerintahan yang baik di dalam menyusun kerangka regulasi dan perijinan yang efisien, efektif, dan non-diskriminatif; menjaga persaingan usaha secara sehat mengembangkan dan melaksanakan iklim persaingan usaha secara sehat dan perlindungan konsumen; mendorong pengembangan standardisasi produk dan jasa untuk meningkatkan daya saing; merumuskan strategi dan kebijakan pengembangan teknologi sesuai dengan pengembangan ekonomi nasional; dan meningkatkan daya saing Usaha Kecil dan Menengah (UKM) sehingga menjadi bagian integral dari keseluruhan kegiatan ekonomi. Untuk itu, dalam kerangka kerja yang diagendakan Bapennas dijelaskan bahwa Kebijakan pasar kerja diarahkan untuk 
mendorong terciptanya sebanyak mungkin lapangan kerja formal serta meningkatkan kesejahteraan pekerja di pekerjaan informal. Pasar kerja yang fleksibel, hubungan industrial yang harmonis dengan perlindungan yang layak, keselamatan kerja yang memadai, serta terwujudnya proses penyelesaian industrial yang memuaskan semua pihak merupakan ciri-ciri pasar kerja yang diinginkan. Selain itu, pekerja diharapkan mempunyai produktivitas yang tinggi sehingga dapat bersaing serta menghasilkan nilai tambah yang tinggi dengan pengelolaan pelatihan dan pemberian dukungan bagi program-program pelatihan yang strategis untuk efektivitas dan efisiensi peningkatan kualitas tenaga kerja sebagai bagian integral dari investasi sumber daya manusia. Sebagian besar pekerja akan dibekali dengan pengakuan kompetensi profesi sesuai dinamika kebutuhan industri dan dinamika persaingan global.

Adapun agenda Bapenas dari Sektor keuangan dikembangkan agar senantiasa memiliki kemampuan di dalam menjaga stabilitas ekonomi dan membiayai tujuan pertumbuhan ekonomi yang berkualitas serta mampu memiliki daya tahan terhadap kemungkinan gejolak krisis melalui: implementasi sistem Jaring Pengaman Sektor Keuangan Indonesia, peningkatan kontribusi Lembaga Jasa Keuangan Non-Bank dalam pendanaan pembangunan, serta peningkatan kualitas pertumbuhan perbankan nasional. Dengan demikian, setiap jenis investasi (baik jangka pendek maupun jangka panjang) akan memperoleh sumber pendanaan yang sesuai dengan karakteristik jasa keuangan. Selain itu, semakin beragamnya lembaga keuangan akan memberikan alternatif pendanaan lebih banyak bagi seluruh lapisan masyarakat.

Perbaikan pengelolaan keuangan negara sesuai dengan agenda bapenas bertumpu pada sistem anggaran yang transparan, bertanggung jawab, dan dapat menjamin efektivitas pemanfaatan. Dalam rangka meningkatkan kemandirian, peran pinjaman luar negeri dijaga pada tingkat yang aman, sementara sumber utama dalam negeri yang berasal dari pajak terus ditingkatkan efektivitasnya. Kepentingan utama pembiayaan pemerintah adalah penciptaan pembiayaan pembangunan yang dapat menjamin kemampuan peningkatan pelayanan publik baik di dalam penyediaan pelayanan dasar, prasarana dan sarana fisik serta ekonomi, dan mendukung peningkatan daya saing ekonomi.

Senada dengan agenda Bapenas tersebut, melalui hasil pengamatan dan penelitian para ahli terhadap pembangunan ekonomi, lahir teori-teori yang kemudian menjadi landasan proses pembangunan ekonomi. diantaranya;

\section{Teori Depedensia}

Teori ini berusaha menjelaskan penyebab keterbelakangan ekonomi yang dialami oleh NSB. Asumsi dasar teori ini adalah pembagian perekonomian dunia menjadi dua golongan, yang pertama adalah perekonomian negara-negara maju dan kedua adalah perekonomian NSB. Andrea Gunder Frank menampilkan tiga hipotesis utama yang relevan, yang berkaitan dengan pola hubungan antara negara maju dan miskin tersebut ( Arief dan Sasono, 1991: 25-7 ), yaitu:

a. Dalam struktur metropolis dan satelit seperti di atas, pihak metropolis akan berkembang dengan pesat sedangkan pihak satelit akan menuju kepada keterbelakangan yang terus menerus.

b. Negara- negara miskin yang sekarang menjadi satelit dapat mengalami perkembangan ekonomi yang sehat dan mampu menumbuhkan perkembangan industri yang otonom apabila kaitan dengan metropolis dari dunia kapitalis internasional tidak ada atau sangat lemah.

c. Kawasan-kawasan yang sekarang sangat terbelakang dan berada dalam situasi 
yang mirip dengan situasi dalam sistem feodal adalah kawasan yang ada pada masa lalu mamiliki kaitan kuat dengan metropolis dari sistem kapitalis internasional. Kawasan-kawasan ini adalah kawasan penghasil komoditas ekspor bahan mentah primer yang terlantar sebagai akibat adanya gelombang konjungtur dalam perdagangan internasional komoditas tersebut.

\section{Kaum Neo-Klasik Penentang Revolusi}

Dekade 1980-an menandai munculnya teori pembangunan Neo-Klasik yang menjawab sanggahan teori dependensia.Teori pembangunan Neo-Klasik yang anti terhadap pendekatan revolusioner sering disebut sebagai teori sisi penawaran ( supply side theory ). Teori ini merekomendasikan swastanisasi BUMN, meningkatkan peran perencanaan dan penetapan regulasi ekonomi yang menciptakan iklim kondusif bagi peningkatan peran pihak swasta dalam pembangunan. Dengan kata lain, mereka menyatakan bahwa keterbelakangan bukan disebabkan oleh pengaruh eksternal, tetapi lebih pada pengaruh internal dalam NSB tersebut. Besarnya derajat campur tangan pemerintah dalam aktivitas ekonomi, merebaknya korupsi, dan kurangnya intensif ekonomi, serta kesalahan dalam pengalokasian sumberdaya, merupakan sumber utama keterbelakangan itu. Dalam teori ini dikemukakan bahwa alokasi sumber daya yang salah menyebabkan kebijakan penetapan harga menjadi tidak efektif dan ditambah dengan campur tangan pemerintah yang terlalu besar dalam perekonomian.

\section{Teori-Teori "Baru"}

\section{a. Teori Pertumbuhan Baru (NGT)}

Teori pertumbuhan baru, yang pada dasarnya merupakan teori pertumbuhan endogen, memberikan kerangka teoritis untuk menganalisis pertumbuhan endogen karena menganggap pertumbuhan GNP lebih ditentukan oleh sistem proses produksi dan bukan berasal dari luar sistem. Berbeda dengan teori tradisional neoklasik yang menganggap pertumbuhan GNP sebagai akibat dari keseimbangan jangka panjang. Motivasi dasar dari teori NGT adalah menjelaskan perbedaan tingkat pertumbuhan antarnegara dan proporsi yang lebih besar dari pertumbuhan yang diamati.

\section{b. Teori Geografi Ekonomi Baru (NEG)}

Salah satu sumbangan yang paling penting teori neo klasik adalah pengenalan terhadap keuntungan-keuntungan aglomerasi (Preer, 1992:34). Pelopor teori neo klasik mengajukan argumentasi bahwa aglomerasi muncul dari perilaku para pelaku ekonomi dalam mencari penghematan aglomerasi, baik penghematan lokalisasi maupun urbanisasi.Sebagaimana diidentifikasi oleh Krugman : Pertama, lokasi kegiatan ekonomi dalam suatu negara merupakan topik yang penting dengan sendirinya.... kedua, garis antara ilmu ekonomi internasional dengan ilmu ekonomi regional menjadi semakin kabur... ketiga, alasan yang paling penting untuk melihat kembali geografi ekonomi adalah laboratorium intelektual dan empiris yang disediakannya (Krugman, 1991:8).

\section{c. Teori Perdagangan Baru (NTT)}

Teori keunggulan komparatif mengajukan dalil bahwa : (1) negara berdagang untuk memperoleh keuntungan dari perbedaan sumber daya alam yang mereka miliki; (2) daerah akan berspesialisasi berdasarkan keunggulan komparatif yang mereka miliki.

Berdasarkan ulasan diatas, Menjadi
tantangan kita bersama untuk
mengembangkan semangat dan suasana yang
mendorong tumbuhnya kemitraan dan
mengembangkan pola-pola yang praktis dan
menarik,serta menjamin keuntungan bagi
semua pihak. Dalam hal ini, pihak-pihak


yang terlibat tentu harus memiliki tanggung jawab karena kemitraan bukanlah bertepuk sebelah tangan. Meskipun semua pihak memiliki tanggung jawab, pemerintah tetap harus mengambil prakarsa paling tidak untuk menciptakan iklim yang merangsang bagi usaha kemitraan, antara lain dengan:

a. Mengembangkan kebijaksanaan dan strategi pembangunan yang jelas, yang tercermin baik pada tujuan, arahan maupun indikator-indikator kebijaksanaan (policy indicators).

b. Menetapkan prioritas pembangunan yang realistis dan diikuti oleh semua pihak, baik pemerintah maupun dunia usaha dan masyarakat. Untuk itu perlu kesepakatan di antara berbagai pelaku pembangunan ini, dan karena itu perlu ada dialogdialog.

c. Memantapkan mekanisme komunikasi yang lancar dan transparan. Transparansi erat kaitannya dengan tingkat partisipasi dan oleh karena itu, sejak pada tahap awal mekanisme kemitraan yang transparan harus dikembangkan dan dimantapkan.

d. Mengembangkan pilihan-pilihan atas pola-pola kemitraan yang dapat mencakup kepentingan-kepentingan yang ada di berbagai lapisan dan golongan masyarakat, sehingga masyarakat dapat berperanserta seluas-luasnya dalam kemitraan pembangunan.

e. Menyiapkan rencana pengembangan kemitraan yang mencakup rencana investasi pemerintah, swasta dan masyarakat sebagai bagian dari pembangunan nasional.

f. Menyiapkan kerangka peraturan dan arahan serta pedoman yang dapat menjadi acuan terutama bagi swasta dan masyarakat dan juga menjamin kepastian usaha. (Kartasasmita, 1996)

Pengembangan kemitraan dalam pembangunan dapat mencakup dua pola dasar, yaitu pertama, dalam bentuk peran serta swasta dan masyarakat dalam pembangunan yang sifatnya memberikan lebih banyak peluang untuk berpartisipasi pada kegiatan yang semula merupakan tugas pemerintah. Atau dengan kata lain, pemerintah memberi ijin pemanfaatan aset milik pemerintah (konsesi)kepada pihak swasta dan masyarakat untuk digunakan dalam jangka waktu tertentu guna melakukan tugas-tugas pelayanan umum. Kedua, kerjasama kemitraan antara masyarakat, swasta dan pemerintah melalui pengembangan formula pembagian modal kerja yang menjadi tanggung jawab masingmasing pihak. Dalam rangka ini dikembangkan pola -pola kerjasama kemitraan yang mencakup pembagian keuntungan dan sekaligus juga risikonya. Untuk mewujudkan kemitraan dalam bentukbentuk tersebut, perlu kesepakatan dalam persepsi kemitraan antara swasta maupun pemerintah. Swasta tidak hanya mempertimbangkan aspek keuntungan ekonomi jangka pendek saja, apalagi yang bersikap spekulatif, tetapi sudah harus memperhatikan kesinambungan pembangunan, atau lebih mengkonseptualisasikan pemikiran investasi yang berwawasan jangka panjang mengenai infrastruktur, yang tujuannya adalah mencari jalan yang tepat untuk mendorong kemitraan dan partisipasi swasta dalam pembangunan prasarana.

Dari asumsi tersebut disimpulkan bahwa yang terpenting bukanlah dana,tetapi justru perlunya kebijakan dan kerangka yang jelas untuk membangun kemitraan antara pemerintah dan swasta dalam pembangunan infrastruktur. Adanya kerangka itu dapat mengurangi ketidakpastian yang sampai sekarang ini dirasakan, khususnya di kalangan swasta,misalnya kerangka tentang kelembagaan, kontrak, dan produksi termasuk jasa.Secara potensial ada peluangpeluang yang terbuka lebar untuk menumbuhkembangkan kemitraan yang saling menguntungkan dalam pembangunan 
nasional, khususnya dalam pembangunan perkotaan. Potensi dan peluang yang besar ini terutama dikarenakan makin meningkatnya kemampuan masyarakat untuk memperoleh pelayanan yang makin berkualitas dengan sistem penyediaan yang lebih baik.Kemampuan masyarakat untuk membayar pelayanan yang lebih baik tersebut memberi landasan perekonomian yang kuat bagi pengembangan kemitraan dalam penyediaan pelayanan prasarana dan sarana. Kegiatan perekonomian yang digerakkan oleh swasta dan masyarakat mencapai sekitar 60-70 persen dan sekitar 80 persen kegiatan pembangunan digerakkan oleh dunia usaha dan masyarakat. Pihak swasta telah melaksanakan kegiatan pembangunan dalam berbagai sektor, dalam skala mikro maupun makro serta secara mandiri maupun bermitra dengan pemerintah.

Peran swasta itu dapat diperkirakan akan terus meningkat,seiring dengan Penyediaan pelayanan prasarana dan sarana perkotaan, industri, dan permukiman, dapat dikembangkan atas dasar kemitraan antara pemerintah, swasta dan masyarakat. Selama ini kemitraan telah berkembang dalam prasarana ekonomi yang kelayakannya tinggi, seperti jalan tol, listrik, telepon. Namun, khusus di kota-kota megapolitan, metropolitan,dan kota-kota besar lainnya, peluang kemitraan dalam penyediaan air bersih, prasarana dan sarana penyehatan lingkungan, persampahan, jalan kota, rumah sakit, sekolah-sekolah unggulan, dan prasarana serta sarana sosial lainnya terbuka cukup lebar.

Berkaitan dengan peningkatan peran swasta dalam berbagai bentuk pembangunan skala besar maka kegiatannya perlu dilaksanakan dalam suatu kerangka sistem yang lebih luas, di samping pembangunan sistem internal Dengan demikian, dapat terwujud keterpaduan dan sinkronisasi sistem yang berdampingan atau berdekatan, baik yang dibangun pemerintah maupun yang dibangun oleh swasta. Dengan kata lain, sinkronisasi pembangunan regional merupakan tantangan yang harus diatasi dengan meningkatnya berbagai bentuk pembangunan skala besar oleh pihak swasta. Dalam banyak hal, memang kegiatan swasta sudah tidak lagi berskala mikro, tetapi sudah sampai pada skala makro yang berdampak makro pula, seperti pengembangan permukiman skala besar atau kota baru, penyediaan sistem telekomunikasi melalui satelit, pembangunan pusat-pusat tenaga listrik, pelabuhan, dan sebagainya. Mengingat makin besarnya bentuk dan nilai partisipasi swasta dalam pembangunan ekonomi yang berskala besar seperti itu, maka sinkronisasi investasi pembangunan menjadi imperatif agar terjadi sinergi yang optimal antara berbagai pelaku pembangunan ekonomi. Kegiatan yang saling tumpang tindih harus dapat dihilangkan. Di sisi lain, adanya sinkronisasi dapat mengisi 'gap' atau kekosongan dari suatu kegiatan pembangunan. konsep Three-Sector Partnership dalam Pembangunan Ekonomi adalah pola yang sesuai dengan prinsipprinsip partisipasi masyarakat yang seluasluasnya yang ingin kita dorong dalam perekonomian dan pembangunan.

Konsep Three-Sector Partnership dalam Pembangunan Ekonomi juga dapat memberi pemecahan atas dilema efisiensi dan pemerataan kesempatan, karena efisiensi tidak mengharuskan pemusatan kekuatan ekonomi pada kelompok tertentu. Kemitraan konsep Three-Sector Partnership dalam Pembangunan Ekonomi merupakan jawaban terhadap monopoli yang dalam sistem ekonomi pasar dan liberal menjadi penyakit yang senantiasa menjadi masalah bagi negara yang menganut paham itu. Kemitraan haruslah didorong tidak saja antara pemerintah dengan usaha besar, tetapi juga dengan usaha kecil dan koperasi, serta antara usaha swasta besar, menengah dan kecil. Dengan demikian kemitraan adalah usaha 
yang tepat dan tidak bertentangan dengan prisip-prinsip ekonomi yang mendasar, dalam membangun ekonomi yang berdasarkan demokrasi.

\section{KESIMPULAN}

Indonesia yang Maju dan Mandiri menuntut kemampuan ekonomi untuk tumbuh ,berkelanjutan, mampu meningkatkan pemerataan dan kesejahteraan masyarakat secara luas, serta berdaya saing tinggi didukung oleh penguasaan dan penerapan ilmu pengetahuan dan teknologi di dalam mengembangkan sumber-sumber daya pembangunan. Peranan pemerintah yang efektif dan optimal diwujudkan sebagai fasilitator, regulator, sekaligus sebagai katalisator pembangunan di berbagai tingkat guna efisiensi dan efektivitas pelayanan publik, terciptanya lingkungan usaha yang kondusif dan berdaya saing, dan terjaganya keberlangsungan mekanisme pasar. Konsep Three-Sector Partnership dalam Pembangunan Ekonomi juga dapat memberi pemecahan atas dilema efisiensi dan pemerataan kesempatan, karena efisiensi tidak mengharuskan pemusatan kekuatan ekonomi pada kelompok tertentu. Agar terwujud kemitraan yang saling mendukung, maka perlu diciptakan iklim yang menggairahkan dengan perangkat dan pranata yang memadai.

Kemitraan pada hakikatnya merupakan wujud yang ideal dalam peranserta masyarakat dalam pembangunan. Kemitraan didasari atas hubungan antarpelaku yang bertumpu pada ikatan usaha yang saling menunjang dan saling menguntungkan, serta saling menghidupi berdasarkan asas kesetaraan dan kebersamaan. Disamping itu juga pentingnya untuk Mengembangkan pilihan-pilihan atas pola-pola kemitraan yang dapat mencakup kepentingan-kepentingan yang ada di berbagai lapisan dan golongan masyarakat, sehingga masyarakat dapat berperanserta seluas-luasnya dalam kemitraan pembangunan. Dengan peningkatan partisipasi dalam konsep Three-Sector Partnership maka diharapkan adanya kesiapan matang dalam rencana pengembangan kemitraan yang mencakup rencana investasi pemerintah, swasta dan masyarakat sebagai bagian dari pembangunan nasional. 


\section{DAFTAR PUSTAKA}

Mustofa, Chabib. 2007. Diktat Perkuliahan Studi Pembangunan. Surabaya: IAIN Sunnan Ampel Surabaya.

Kuncoro, Mudrajad. 2003. Ekonomi Pembangunan. Yogyakarta: LPP AMP YPKN.

Todaro, Michael. Pembangunan Ekonomi. Jakarta: Erlangga

Arsyad, Lincolin. 2004. Ekonomi

Pembangunan, cetakan ke-2, Yogyakarta: Bagian Penerbitan Sekolah Tinggi Ilmu Ekonomi YKPN.

Irawan, dan Suparmoko. 1981. Ekonomi Pembangunan, edisi ketiga, Bagian Penerbitan Fakultas Ekonomi Universitas Gadjah Mada.

Kuncoro, Mudrajad. 2010. Dasar-Dasar Ekonomika Pembangunan, Yogyakarta:UPP STIM YKPN

Elkington, John. 1998. Cannibals with Forks: The Triple Bottom Line of 21 Century Business.Philadelphia: New Society.

Keputusan Menteri BUMN No. 236 Tahun 2002 tentang Program Kemitraan dan Bina Lingkungan (PKBL).

Kompas, 22 Oktober 2010. Dana CSR Mampu Tekan Angka Kemiskinan.

Lembaga Administrasi Negara dan Badan Pengawasan Keuangan dan Pembangunan. 2000.Akuntabilitas dan Good Governance. Jakarta: Lembaga Administrasi Negara.
Sampurna, Muhammad.Endro. 2007. Pertanyaan Besar Bagi Penyelenggara Industri Global.http://www.csrindonesia.com/pubtulisa n.php.

Soemanto, Bakdi. 2007. Sustainable Corporation: Implikasi Hubungan Harmonis Prusahaan dan Masyarakat. Gresik: PT Semen Gresik (Persero). Tbk.

Syakhroza, Akhmad. Corporate Governance: sejarah dan Perkembangan, Teori, Model, dan Sistem Governance serta Aplikasinya pada Perusahaan BUMN. Jakarta: Penerbit Fakultas Ekonomi Universitas Indonesia.

United Nations: Departement of Economics and Social Affairs. 2003. Citizens, Business and Governments: Dialogue and Partnerships for Development and Democracy. New York

World Bank. 2002. The Role of Public Sector in CSR http://www.leidykla.eu/fileadmin/Ekon omika/ 86/55-67.pdf

Kartasasmita, Ginandjar. 1996. Kemitraan Dalam Pembangunan Nasional Dengan Tinjauan Khusus Dalam Pembangunan Perkotaan (makalah disampaikan Pada Seminar Nasional Urban and Regional Development Institute (URDI) di Jakarta, 23 September 1996) 